\title{
Anáglifo, fotointerpretação e imagens do Google Earth como alternativa para elaboração do mapeamento geomorfológico da Serra do Corpo Seco- Ituiutaba-MG (Brasil)
}

\author{
Anaglyph, photointerpretation and Google Earth images as an \\ alternative for the preparations of the geomorphological \\ mapping of Serra do Corpo Seco -Ituiutaba-MG (Brazil)
}

Leda Correia Pedro Miyazaki, Docente do Curso de Graduação em Geografia e do Programa de Pósgraduação em Geografia do Pontal, Instituto de Ciências Humanas do Pontal, Universidade Federal de Uberlândia, Brasil, lecpgeo@ufu.br

(1) https://orcid.org/0000-0001-6293-0439

Amanda Aparecida Gomes de Oliveira, Geógrafa, Graduação em Geografia do Pontal, Instituto de Ciências Humanas do Pontal, Universidade Federal de Uberlândia, Brasil,

gomes.amandageo@gmail.com

(1) https://orcid.org/0000-0001-6343-0196

Resumo: O objetivo principal da pesquisa foi elaborar um mapeamento geomorfológico do relevo residual denominado Serra do Corpo Seco, tendo em vista que é considerado como um dos produtos cartográficos relevantes para subsidiar o planejamento ambiental. Para isso, foi utilizado um procedimento metodológico que envolveu o método anáglifo (para gerar uma imagem 3D), a fotointerpretação e imagens de satélite de alta resolução espacial disponíveis no Google Earth, além disso, foi necessário utilizar o ambiente computacional dos aplicativos Stereo Photo Maker e QGIS. O resultado obtido foi satisfatório, uma vez que as bases cartográficas disponíveis e acessíveis, até o momento, não permitiram a realização de mapeamento utilizando pares estereoscópicos de fotografias aéreas. A partir dessas técnicas foi possível espacializar os principais compartimentos geomorfológicos, as feições hídricas e de relevo, o que resultou na identificação de aspectos importantes do relevo local. $\mathrm{O}$ documento cartográfico elaborado é uma importante ferramenta que poderá subsidiar o planejamento ambiental da área, pois apresenta uma série de informações de caráter geomorfológico relevantes para os gestores do município, principalmente no que tange à proteção da Serra do Corpo Seco, que é reconhecida pela população como um patrimônio natural e cultural. Espera-se que esse procedimento metodológico possa auxiliar outros pesquisadores na elaboração de mapeamentos geomorfológicos, visando cada vez mais otimizar a elaboração desse tipo de mapa.

Palavras-chave: Mapeamento; Relevo; Imagens tridimensionais; Anáglifo; Fotointerpretação.

Abstract: The main objective of the research was to elaborate a geomorphological mapping of the residual relief called Serra do Corpo Seco, considered as one of the relevant cartographic products to support environmental planning. For this purpose, a methodological procedure was used that involved the anaglyph method (to generate a 3D image), photointerpretation and high-resolution satellite images available on Google Earth, but to do so, it was necessary to use the computational environment of the Stereo Photo Maker and QGIS applications. The result obtained was satisfactory, since the cartographic bases available and accessible, did not allow mapping using stereoscopic pairs. From these techniques was possible to spatialize the main geomorphological segments, relief and water features which resulted in the identification of important aspects of the local relief. The cartographic document prepared is an important tool that can support the environmental planning of the area, since they present information of geomorphological character relevant to the managers of the municipality, mainly in the preservation and conservation of Serra do Corpo Seco, which is recognized by the population as a natural and 
cultural heritage. This methodological procedure is expected to help other researchers in the elaboration of geomorphological mappings, aiming increasingly to optimize the work.

Keywords: Mapping; Relief; Three dimensional images; Anaglyph; Photointerpretation.

\section{Introdução}

As investigações geográficas com ênfase na geomorfologia têm despertado interesse de vários pesquisadores que buscam compreender os efeitos e as respostas do ambiente diante das intervenções da sociedade na constituição do espaço geográfico. Quando o estudo do relevo é feito sob uma perspectiva geográfica, considerando o tempo histórico/tempo que faz (Suertegaray, Nunes, 2001) e os processos morfodinâmicos atuais (Pedro Miyazaki, 2014), é possível analisá-los a partir da interrelação entre as dinâmicas da natureza e da sociedade, uma vez que esta última é capaz de acelerar os processos naturais que esculturam o relevo e gerar diversos impactos no ambiente.

Neste contexto, a Geomorfologia tem amparado o debate ambiental, e se tornou premente, principalmente quando utilizada para subsidiar o planejamento ambiental e a gestão dos recursos naturais. Assim, para que o planejamento e a gestão se efetive é importante que o inventário do substrato físico-natural apresente uma caraterização que possa ser compreendida pelos gestores e planejadores.

Considerando-se que o relevo é um dos elementos que compõe esse substrato, o levantamento e a análise de suas características têm grande relevância para o planejamento e a gestão ambiental (Cunha, Queiroz, 2012), e deve envolver mapas que espacializam aspectos do relevo de forma didática, que possa ser de fácil leitura e compreensão.

O mapa é um dos produtos cartográficos mais utilizados pelos geógrafos, pois sua finalidade é espacializar determinados fenômenos e informações, como as formas do relevo, sendo importantes para se compreender o espaço geográfico, bem como a paisagem de um determinado local. Assim, a Geomorfologia, que é entendida como aquela que estuda as formas de relevo e os processos (endógenos e exógenos) responsáveis por sua elaboração (Guerra, Guerra, 2006), tem na cartografia geomorfológica uma das mais importantes formas de comunicação e análise dos resultados obtidos (Cunha, Mendes, Sanchez, 2003).

A cartografia geomorfológica tem contribuído muito para subsidiar o planejamento urbano-ambiental, o ordenamento territorial e a gestão de um município, estado e/ou região. Ela é responsável pela análise das representações gráficas e feições dos relevos, tendo por objetivo fundamental, reconhecer os fenômenos que são responsáveis pela sua gênese relacionando-os com todos os processos operantes (Lima, Cunha, Perez Filho, 2012).

Os mapas geomorfológicos são instrumentos/ferramentas essenciais para embasar o planejamento ambiental, pois espacializa informações sobre aspectos do relevo que permitem compreender não apenas a sua distribuição espacial, mas também os 
processos que atuaram no passado e que atuam no presente, sendo responsáveis pelas paisagens geomorfológicas contemporâneas (Griffiths; Abraham, 2007). Para Cunha e Queiroz (2012, p. 1) "a representação cartográfica do relevo pode fornecer dados sobre as condições locais para ocupação ou, ainda, em caso de ocupação já efetiva, pode auxiliar na identificação de áreas potencialmente problemáticas no futuro".

Girão e Corrêa (2004) chama a atenção para o fato que as feições geomorfológicas são elementos bastante relevantes para a sociedade, em primeiro lugar serviu como locus de ocupação, proporcionando recursos para o crescimento de atividades agrícolas junto a planícies de inundação (civilizações egípcias que cultivavam nas planícies do rio Nilo), e em segundo, por sua forma e função, servindo como suporte para o desenvolvimento de diversas atividades, por exemplo a expansão da ação do ser humano sobre o espaço a partir da ocupação do relevo para novas áreas como moradias, estabelecimentos produtivos, novas vias de acesso, novas áreas de plantio e/ou criação, áreas para implantação de aterro sanitário, estação de tratamento de efluentes, distritos industriais, etc. (Girão, Corrêa, 2004; Pedro, 2011).

Balatka e Sladek (1967) consideram que o mapeamento geomorfológico pode contribuir de forma efetiva na resolução de problemas ambientais de caráter geomorfológico, como também evitá-los. Isso deve-se graças à espacialização de formas e feições do relevo, que pode apontar as áreas mais ou menos favoráveis à apropriação e ocupação, evitando impactos ambientais (Pedro, 2011).

É muito importante não apenas espacializar o relevo, mas sobretudo, compreender as suas feições e os processos morfogenéticos, pois ambos são extremamente relevantes para orientação de categorias de uso do solo, tanto nas áreas rurais, quanto nas urbanas (Girão, Corrêa, 2004).

O mapeamento geomorfológico é uma das maneiras mais importantes de divulgação dos resultados de pesquisas sobre o relevo, também é considerado como uma das ferramentas que auxiliam o planejamento urbano-ambiental de municípios, territórios e regiões. No entanto, algumas técnicas de mapeamento, principalmente aquelas que que são específicas para o mapeamento de detalhe, exigem o uso de fotografias aéreas analógicas ou digitais e muitas vezes não estão facilmente acessíveis ao pesquisador ou até mesmo são inexistentes na escala cartográfica de interesse do mapeador.

Diante disso, o objetivo principal da pesquisa foi elaborar um mapeamento geomorfológico do relevo residual denominado Serra do Corpo Seco, tendo em vista que é considerado como um dos produtos cartográficos relevantes para subsidiar o planejamento ambiental.

Justifica-se a realização desse estudo, com ênfase no mapeamento geomorfológico, devido à escassez de pesquisas científicas que forneçam informações e dados básicos para subsidiar o planejamento ambiental da área de estudo, principalmente no caso dos relevos residuais do tipo tabuliformes da Serra do Corpo Seco, onde 
encontram-se nascentes de cursos d' água, local utilizado para realização de práticas de lazer ao ar livre, manifestações religiosas como as afro-brasileiras, sendo considerados pela população como uma das riquezas naturais e culturais.

\section{1. Área de estudo}

O relevo residual do tipo tabuliforme espacializado nessa pesquisa é denominado pelo IBGE (1979) como "Morro São Vicente". No entanto, culturalmente o mesmo é conhecido pelos moradores do município de Ituiutaba como "Serra do Corpo Seco". Esse domínio se encontra localizado no município de Ituiutaba/MG (Figura 1), nas proximidades da área urbana, cujas coordenadas são 19 1' 47"' e 19० 2' 39" Latitude S; 49 27' 72" e 49 28' 66" Longitude W. Exatamente na porção oeste da Mesorregião do Triângulo Mineiro/Alto - Paranaíba, onde o mesmo é sede da Microrregião de Ituiutaba. O município possui uma área de $2.598,046 \mathrm{Km}^{2}$ com uma população de 97,171 habitantes e densidade demográfica de 37,40 hab/Km² (IBGE, 2010).

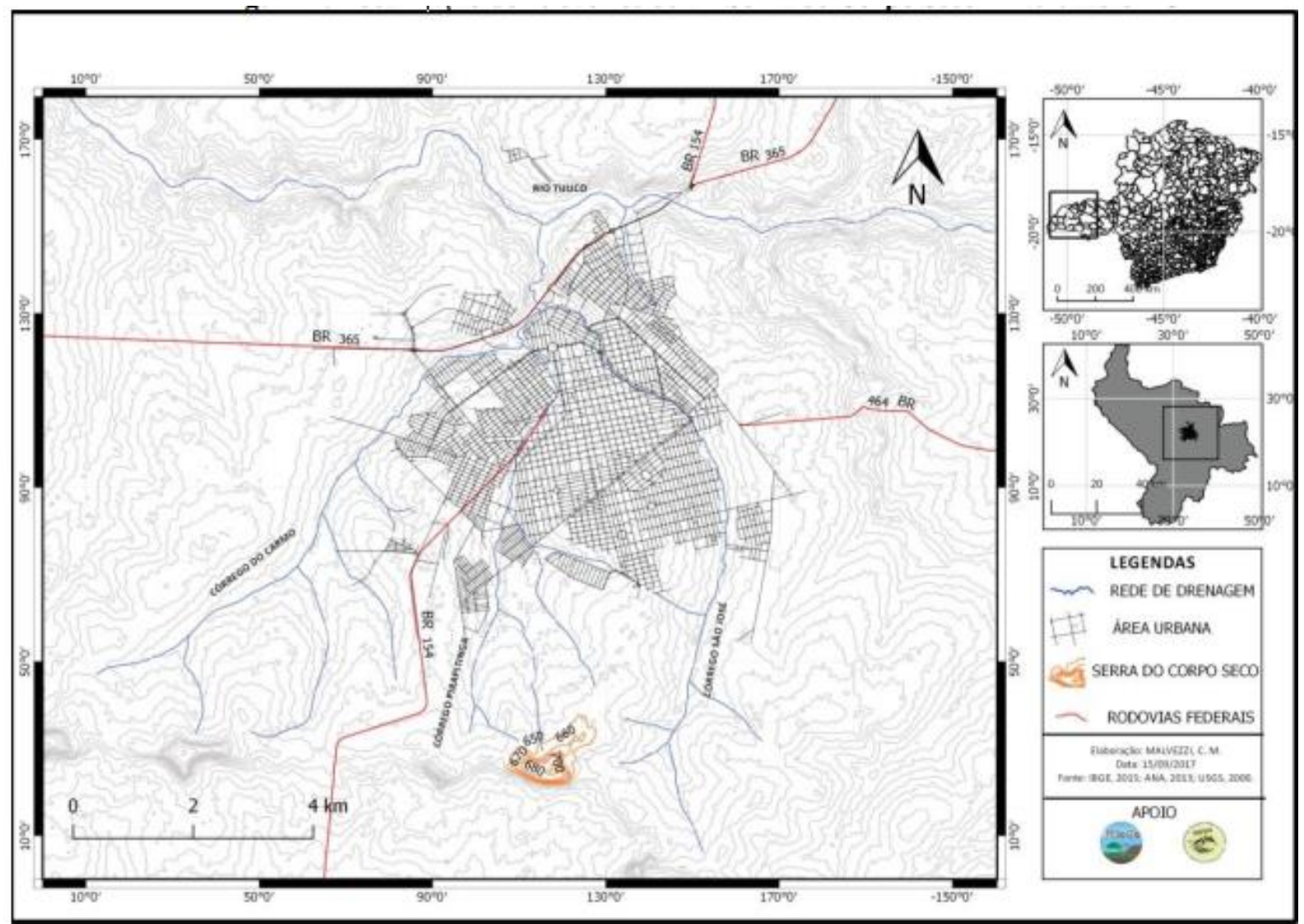

Figura 1: Localização da área de estudo - Serra do Corpo Seco - Ituiutaba/MG Fonte: Malvezzi et al. (2017)

A Serra do Corpo Seco situa-se na porção sul da cidade, local onde se encontram algumas das altitudes mais elevadas, concentrando-se os relevos residuais do tipo tabulares da Formação Marília, Grupo Bauru.

A Serra é constituída geologicamente pela Formação Marília, Grupo Bauru, sendo composta por arenitos grossos a conglomeráticos, textural e mineralogicamente 
imaturos, em bancos maciços ou com incipiente estratificação subparalela e, em determinados locais, estratificação cruzada, pode-se encontrar em determinados locais estratificação cruzada (Soares et al.,1980; Barcelos, 1984; Fernandes, 1998).

Este tipo de relevo tabuliforme é frequentemente localizado em centro de bacias sedimentares, e neste caso específico, encontrados na Bacia Bauru, apresentando formas semelhantes às mesas ou tabuleiros com topo aplainado e vertentes íngremes (Figura 2, A e B), sustentados por camadas sedimentares que apresentam alternância quanto à resistência litológica (Pedro Miyazaki, 2017).

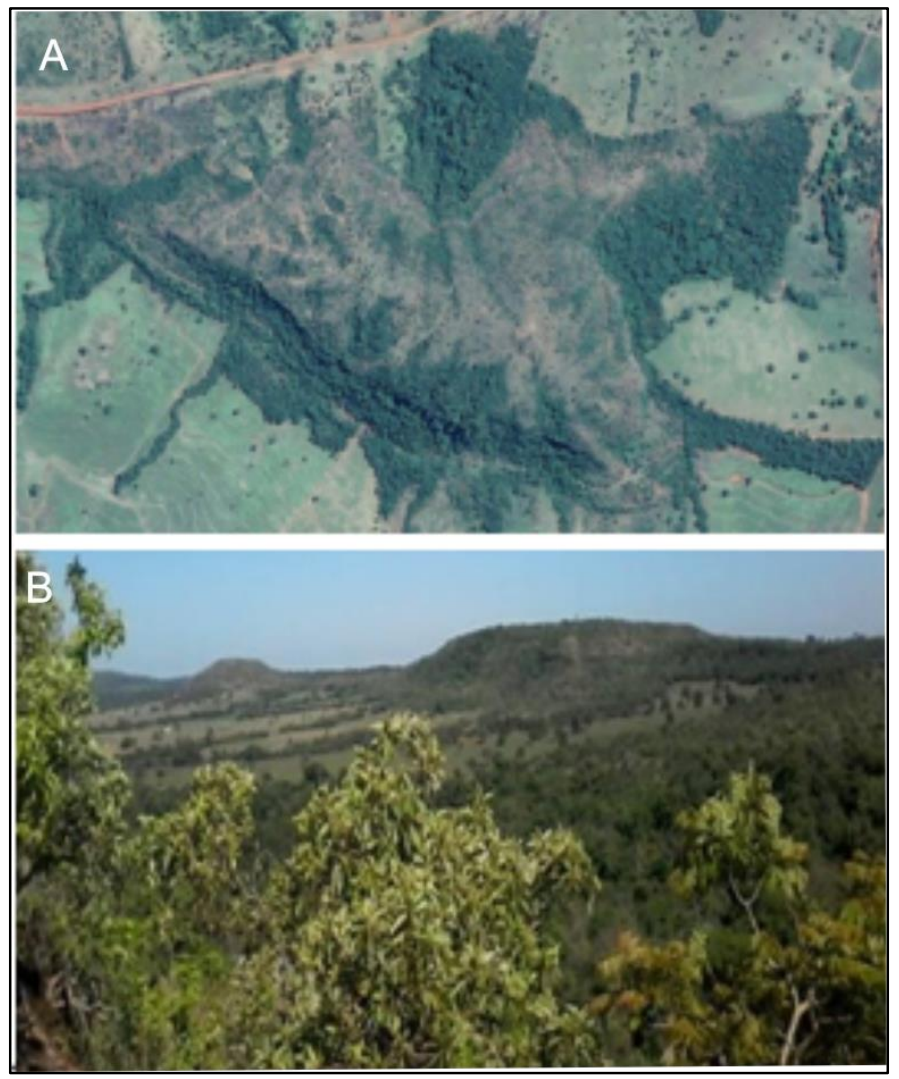

Figura 2: A. Imagem de satélite da Serra do Corpo Seco com destaque para o topo do relevo. B Fotografia com vista parcial da serra.

Fonte: Google Earth (2018); Pedro Miyazaki, Bento (2018)

Por apresentar características arenosas e de formato tabuliforme, a Serra do Corpo Seco possui um grau de fragilidade bastante expressivo, uma vez que vários impactos ambientais (erosões lineares, disposição irregular de resíduos sólidos, queimadas antrópicas) têm agravado o quadro de degradação ambiental, sendo provocadas por pessoas que utilizam a área para praticar lazer, manifestações religiosas e como depósito de resíduos sólidos (lixo).

\section{Material e métodos}

Para a realização desta pesquisa foram utilizados os seguintes materiais: 
- par de imagens de satélite de alta resolução espacial obtidos pelo Google Earth imagens Landsat 8- disponíveis gratuitamente;

- aplicativo StereoPhoto Maker, de uso livre, versão 4.37, disponível gratuitamente para download no endereço: https://stereo.jpn.org/eng/stphmkr/

- óculos para visualização em 3D, com lentes nas cores vermelho e azul;

- aplicativo QGIS para georeferenciar o anáglifo e digitalizar os compartimentos geomorfológicos, feições do relevo e hídricas;

- câmera fotográfica semiprofissional da marca NIKON coolpix L120, para registro de imagens do relevo;

- Notebook DELL Inspirion 15 série 5000.

Para a realização do mapeamento geomorfológico, foram feitas três etapas envolvendo técnicas de elaboração de anáglifos a partir dos procedimentos de Souza e Oliveira (2012), Pedro Miyazaki (2016) e Oliveira (2019), no qual utilizou-se alguns programas e ferramentas que compõem as geotecnologias.

Etapa 1 - Captura das imagens de satélite para formar o par estereoscópico

Para salvar as imagens de satélite que formarão o anáglifo, foi utilizado o aplicativo Google Earth Pro disponível para download gratuito. Nesse programa é possível obter imagens de alta resolução espacial. Para que a captura das imagens seja adequada, é necessário habilitar e configurar o aplicativo.

Ao abrir a imagem da área de interesse no Google Earth, é preciso criar ou inserir um polígono no formato $K M Z$ que envolva toda área de interesse. Após isso, deve-se desabilitar as funções presentes no canto direito da tela, deixando apenas terreno habilitada e para que a qualidade das imagens seja maximizada, é necessário haver a renderização seguindo o comando ferramentas > opções > visualização $3 D$. Neste comando, deve-se seguir a seguinte configuração: True Color 32bits; Alto; Pequeno; DirectX; Graus Minutos e Segundos; Metros quilomêtros; Ampliar elevação em 3 e Use terreno de alta qualidade; Modo de visão habilitada para grande e infinito; Aplicar e OK (Figura 3). 


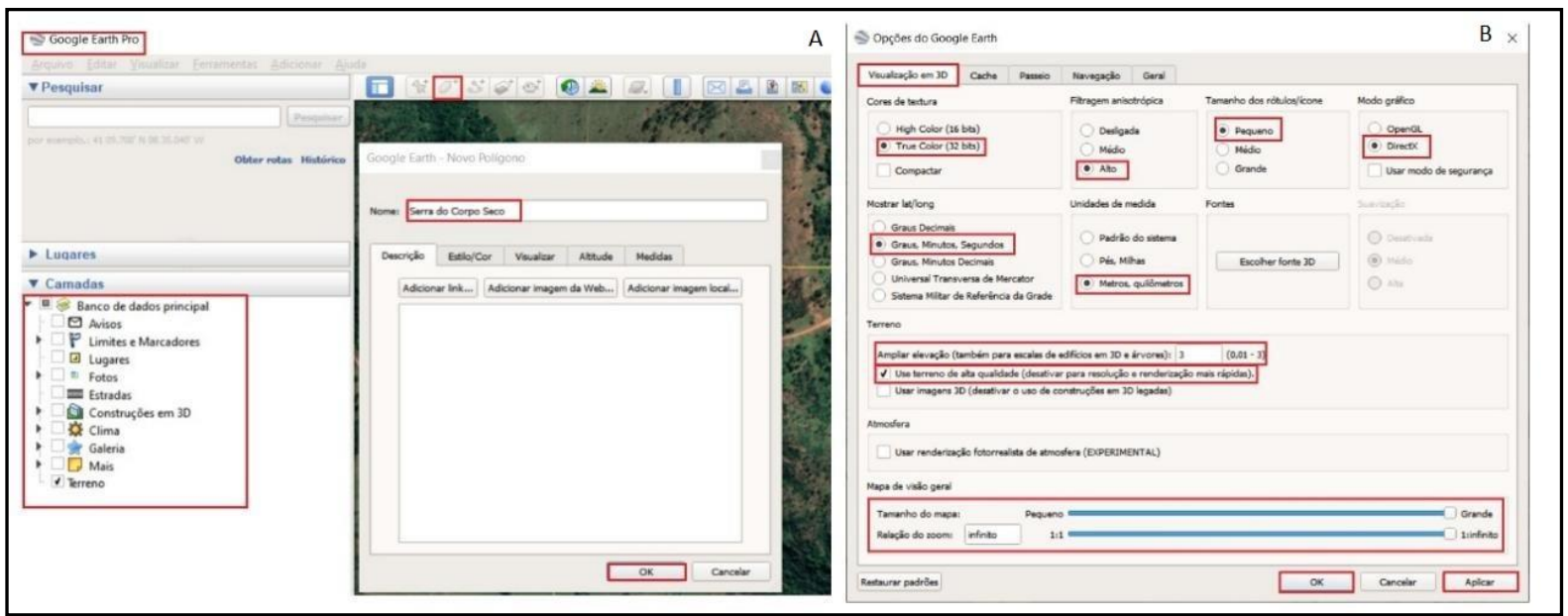

Figura 3: Criação do Polígono da área de estudo e configuração para gerar as imagens.

Fonte: Oliveira (2019)

Como dito anteriormente, para as imagens apresentarem boa qualidade é necessário passarem pelo processo de renderização que se dá a partir das ferramentas visualizar > redefinir > inclinação e bússola. Após esta configuração, é preciso habilitar a tela para que a imagem de satélite possa ser salva e formar os pares estereoscópicos, em seguida desmarcar todos os itens que constam na opção "Elementos". Assim, deve-se retirar a coluna do lado direito no botão na barra de funções, depois, ir em Arquivo > salvar imagem > opções de mapas e desmarcar todas as opções e a resolução da imagem deve ser colocada em máxima (4800x2273) (Figura 4).

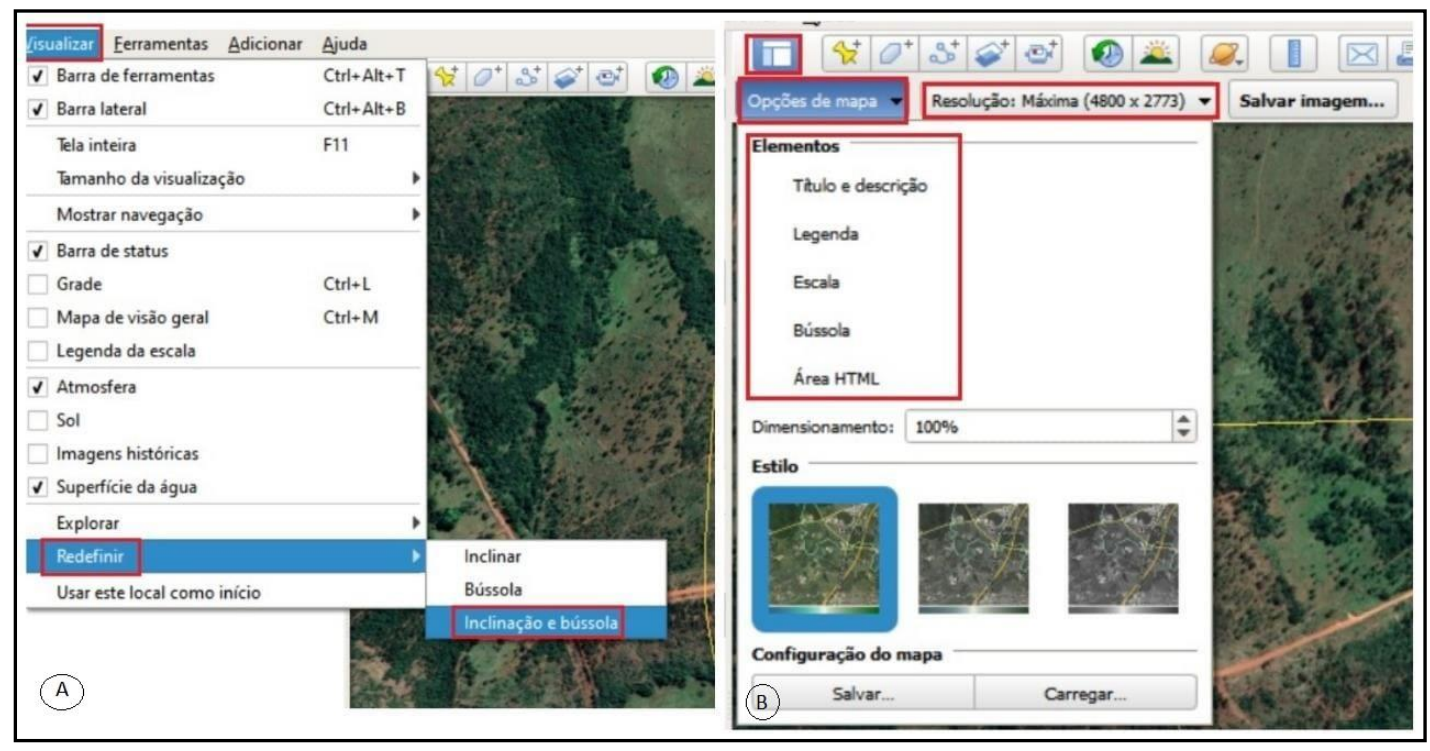

Figura 4: Renderização da imagem e habilitação para captura. Fonte: Oliveira (2019)

Por fim, a etapa de captura do par de imagem, que deve ser feito a partir da movimentação lateral para direita e esquerda, deixando sempre um espaço entre a 
área e a tela de visualização para que assim, seja possível transpor as imagens. Quando mover para a direita, nomear o arquivo como "imagem esquerda"; quando mover para esquerda, nomear como "imagem direita" (Figura 5).
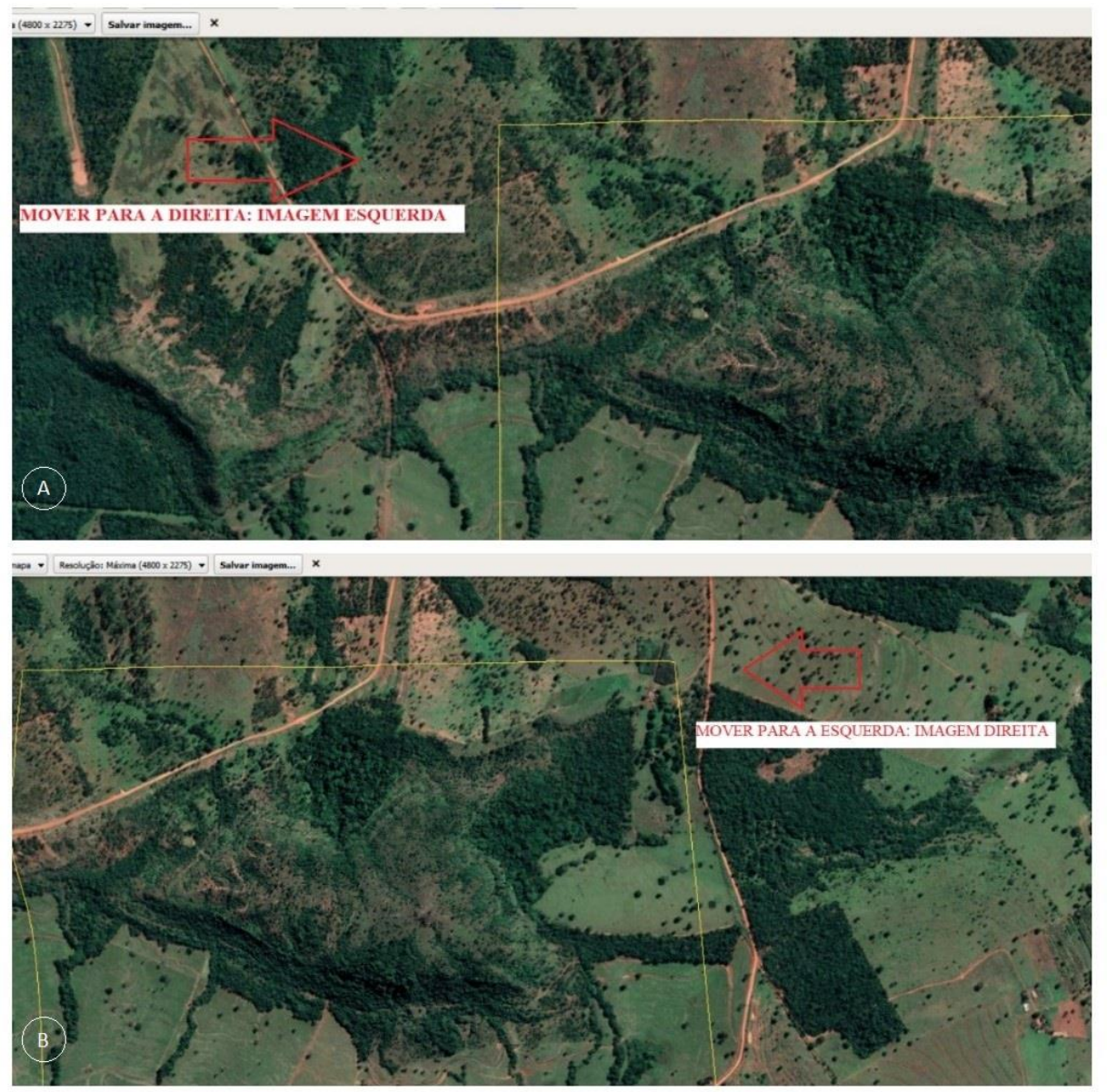

Figura 5: A. Movimentação da imagem para a direita. B. Movimento da imagem para a esquerda. Ambas imagens foram salvas a partir de pontos de observação distintos (com pequeno deslocamento).

Fonte: oliveira (2019)

\section{Etapa 2 - Elaboração do anáglifo}

O StereoPhoto Maker é um aplicativo disponível gratuitamente que tem como funcionalidade editar e visualizar imagens podendo gerar um anáglifo de cores vermelho-ciano, vermelho-verde, vermelho-azul e amarelo-azul. O resultado final pode ser salvo em .jpeg, .stj, .tiff, .gif, sendo o formato escolhido a partir do objetivo do anáglifo e o software utilizado para a sua interpretação.

Para que os anáglifos sejam gerados é necessário seguir os seguintes passos:

1 - Abrir o par de imagens de satélites com alta resolução no aplicativo StereoPhoto Maker, para isso utilizar a barra de funções seguindo os comandos file > open left/right images (Figura 6). 


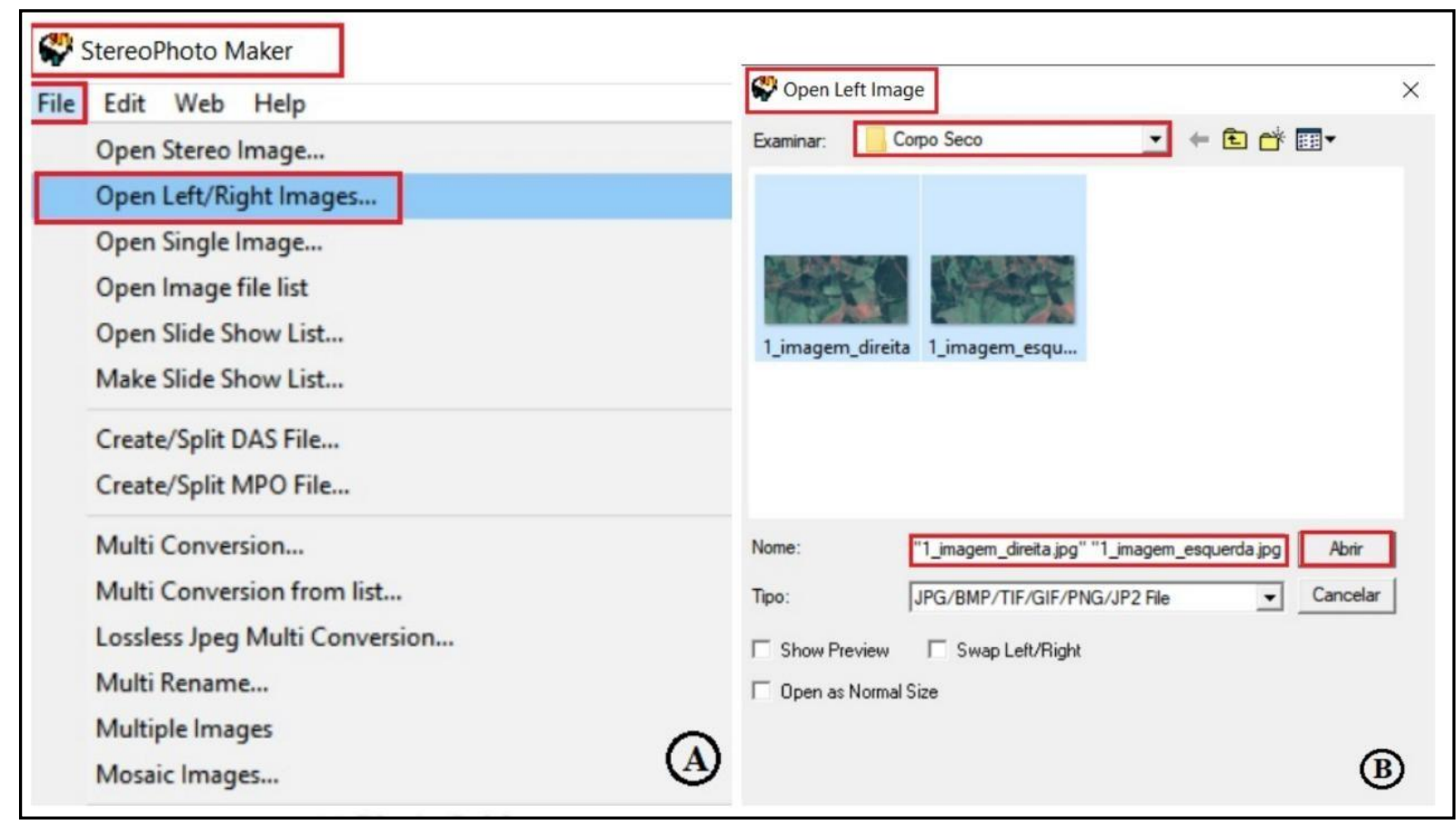

Figura 6: Primeira etapa para a elaboração do anáglifo, abrir e visualizar o par estereoscópico.

Fonte: Pedro Miyazaki (2018) e Oliveira (2019)

2 - Após a abertura das imagens, estas serão postas lado a lado no aplicativo e assim deve-se iniciar a sua configuração para aplicação da falsa cor. Para isso, é necessário seguir na barra de funções: stereo > color Anaglyph > color (red/cyan) (Figura 7 A). Para prosseguir com a configuração, é necessário a realização do ajuste das imagens (Figura 7 B), em que os comandos adjust > easy adjustment devem ser selecionados.

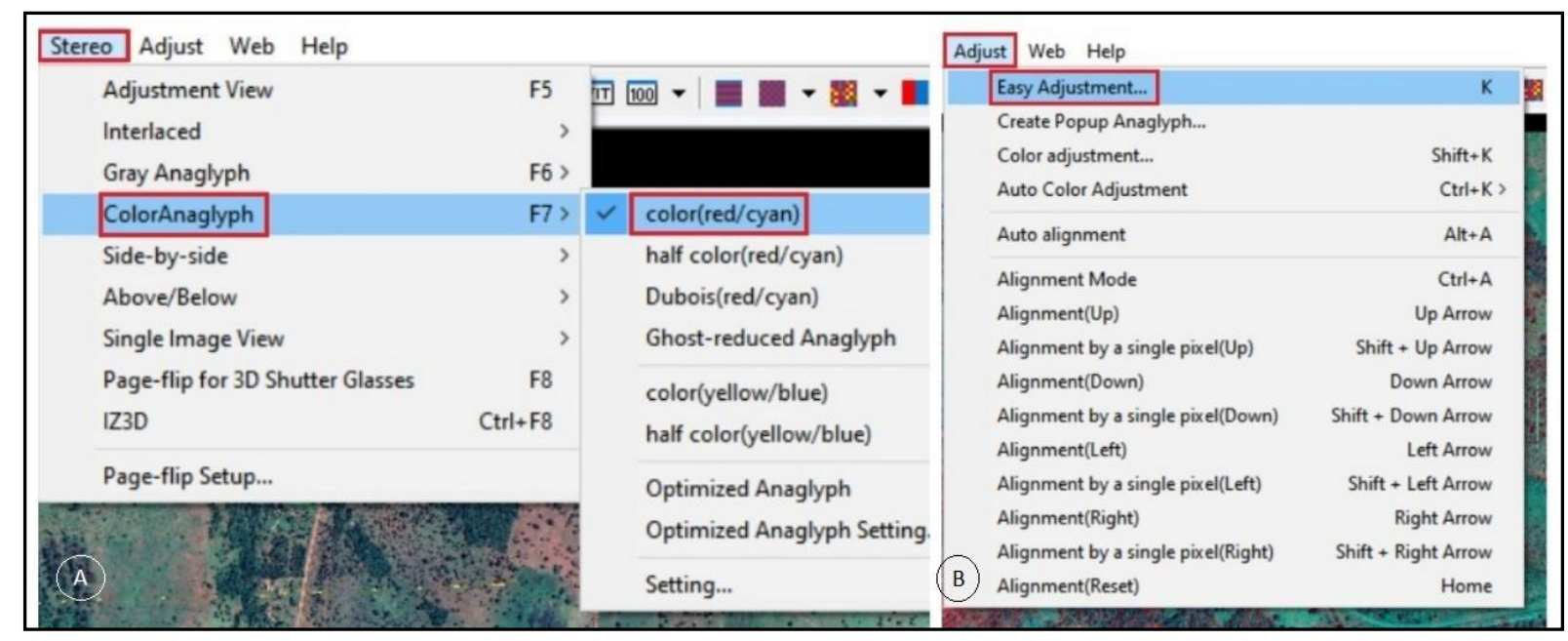

Figura 7: Etapa de aplicação da falsa cor e ajuste do anáglifo.

Fonte: Oliveira (2019)

Para que o ajuste seja feito de forma correta, é necessário a utilização dos óculos 3D (Figura $8 \mathrm{~A}$ ), isso fará com que o mapeador consiga observar o objeto de estudo de forma tridimensional. Assim, selecionando o comando easy adjust uma nova aba será 
aberta, para que o encaixe das duas imagens com pontos em comum seja sobreposto (Figura 8 B).

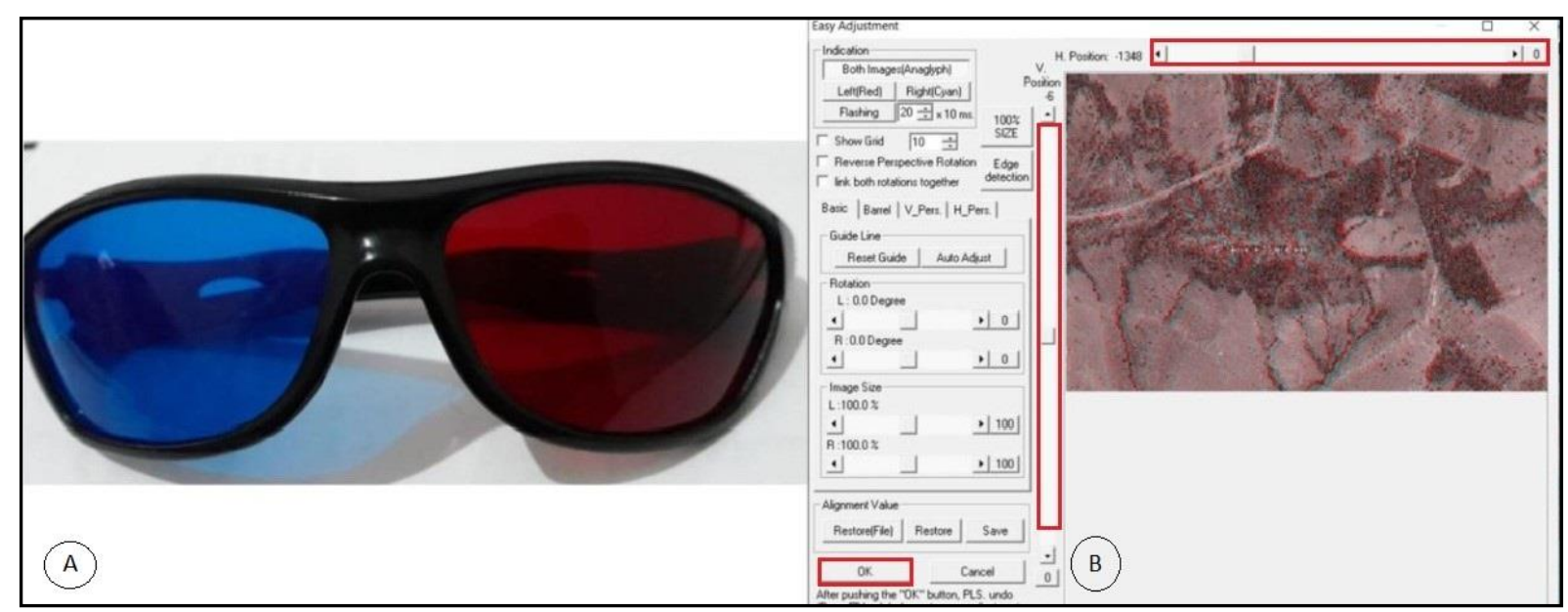

Figura 8: A. Óculos 3D anáglifo para visualização do relevo. B. Etapa de sobreposição das imagens (fusão) por meio da ferramenta de ajuste.

Fonte: Oliveira (2019)

Com a sobreposição correta das imagens (par estereoscópico com falsa cor), devese clicar em OK e assim o anáglifo será gerado e com a utilização dos óculos 3D é possível verificar na imagem a profundidade (Figura 9).

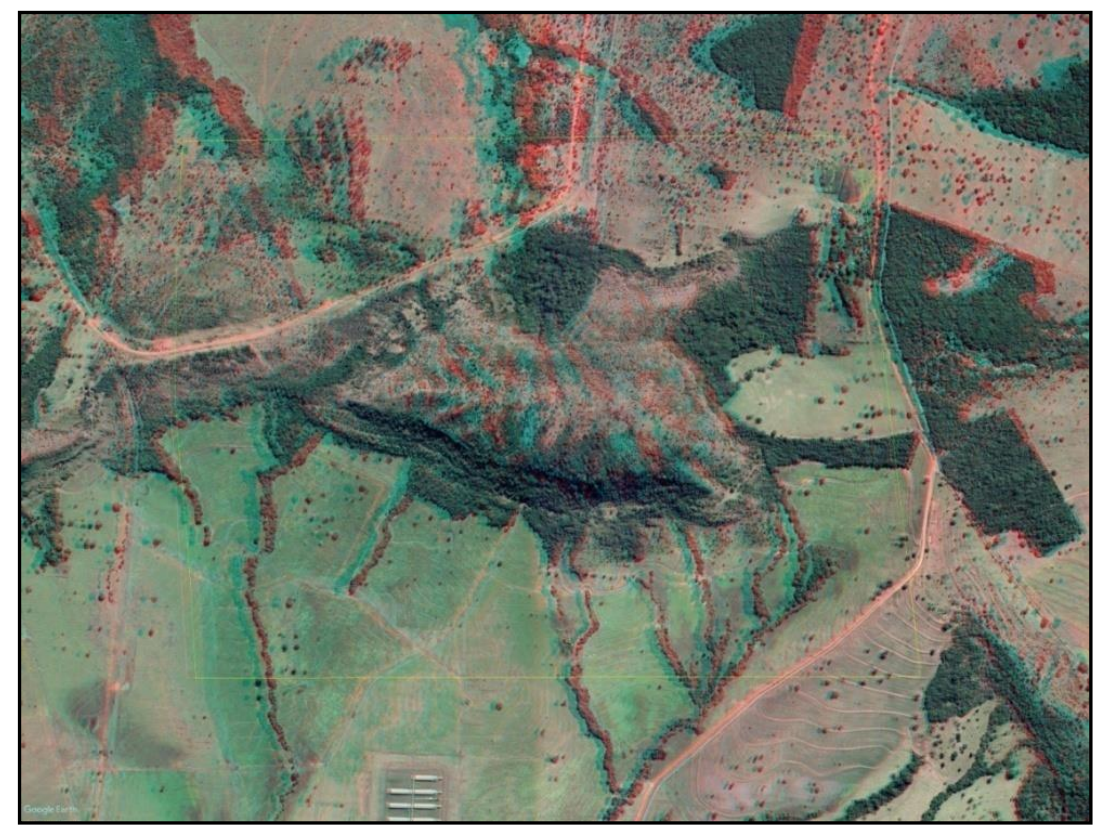

Figura 9: Etapa final com o anáglifo gerado.

Fonte: Oliveira (2019)

Para que a imagem seja salva, deve-se ir em file > save stereo image e salvar no formato desejado, lembrando que para essa escolha o software de destino deve ser levado em consideração. 
Etapa 3 - Georeferenciamento e digitalização dos compartimentos e feições hídricas e do relevo

Para que as feições possam ser extraídas do anáglifo, ele deve ser georreferenciado. Para que isso fosse possível, utilizou-se o software QGIS 2.18.19, no qual foi aberto uma imagem CBERS georeferenciada da área de estudo.

Com a imagem aberta, utilizou-se a seguinte sequência de ferramentas: menu > raster > georreferenciador > georreferenciar. Assim, vinte pontos foram escolhidos para controle na imagem CBERS, de modo que a margem de erro fosse a menor possível: menu > adicionar ponto.

Após o georreferenciamento do anáglifo foi iniciada a etapa de digitalização dos compartimentos geomorfológicos, feições hídricas e do relevo. Para isso, é adotada a sequência de digitalização dos trabalhos de Nunes, Freire e Perez (2006), Fushimi (2009) e Pedro Miyazaki (2016, 2017).

A digitalização dos compartimentos e feições seguiu a sequência didáticometodológica apresentada na figura 10.

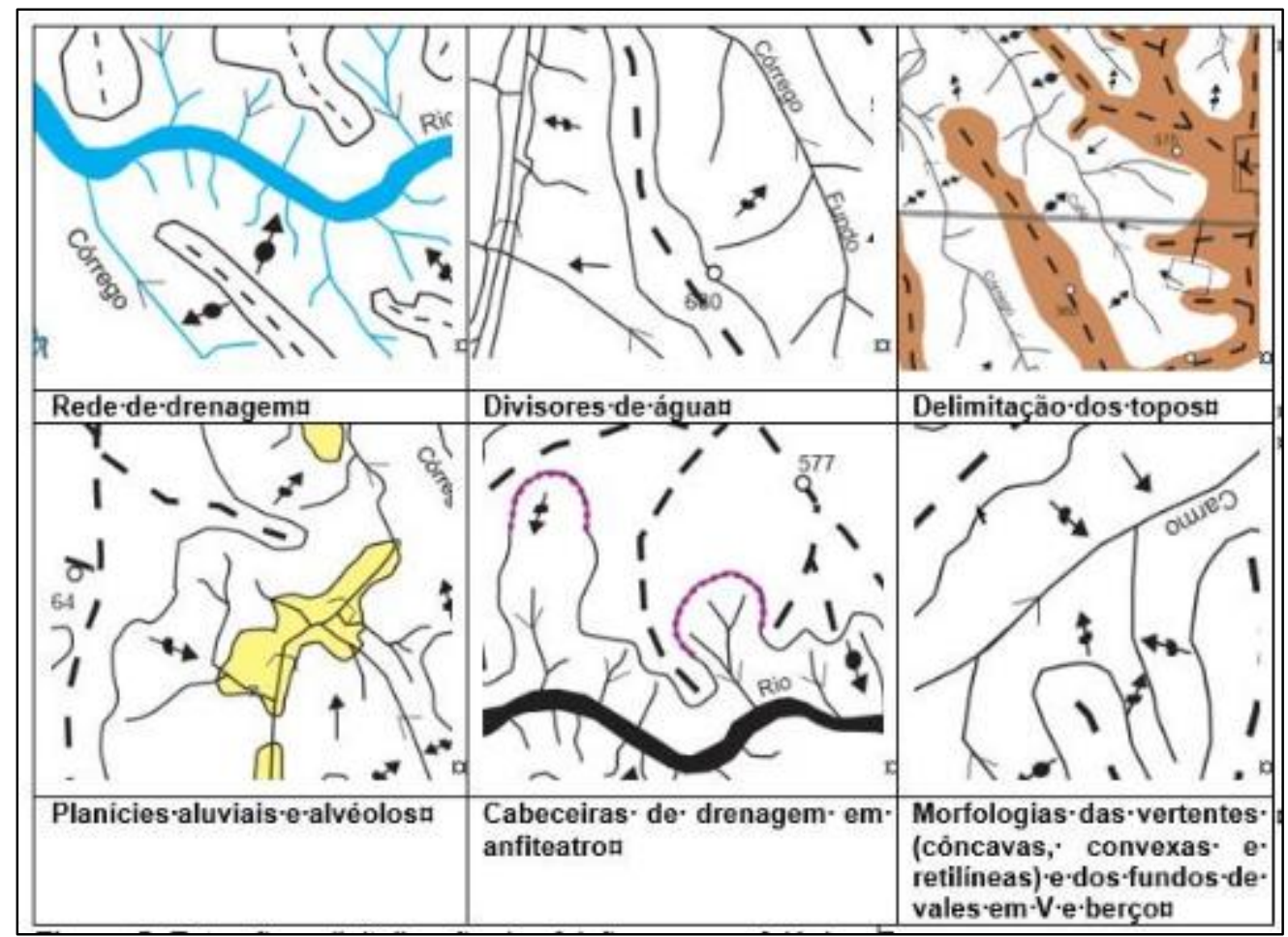

Figura 10: Sequência de digitalização dos compartimentos geomorfológicos e feições hídricas e do relevo.

Fonte: Pedro Miyazaki (2016)

A primeira feição que foi mapeada refere-se a rede de drenagem, seguida pelo divisor de águas, os limites dos topos, as vertentes (compartimento e formas), as cabeceiras de drenagem e morfologia de fundos de vale. 
Cada aspecto mapeado resultou em um shape obtido através da interpretação do anáglifo georreferenciado. A digitalização foi feita a partir dos comandos: camada > criar nova camada > shapefile.

Para cada feição identificada, uma nova camada deve ser inserida. Para a realização deste mapeamento, iniciou-se a construção de camadas seguindo divisor de águas > drenagem > topos > vertentes e, por conseguinte, foram utilizados símbolos para a classificação destes compartimentos.

Por último, foi realizada a validação do mapeamento a partir de trabalhos de campo, essa etapa foi fundamental para conferência do mapeamento onde foi possível averiguar se a representação cartográfica estava de acordo com os aspectos interpretados e mapeados pelos pesquisadores.

\section{Resultados e discussões}

Identificar as formas do relevo, assim como as feições geomorfológicas presentes na área de estudo é o papel da cartografia geomorfológica. Os documentos cartográficos de detalhe ou semidetalhe contribuem para se entender o relevo local, suas implicações e de forma efetiva para o planejamento urbano-ambiental dos municípios. Os mapeamentos geomorfológicos fornecem informações espaciais importantes para o ordenamento territorial, além de ser importantíssimo para os estudos de expansão territorial, ordenamento ambiental, fragilidade, vulnerabilidade, riscos, etc.

O grau de detalhe obtido na pesquisa está relacionado com a compartimentação realizada no relevo, em que foram identificados e delimitados compartimentos geomorfológicos que envolveram os topos, vertentes, fundos de vale, além de ser importante para a identificação de outras feições do relevo como as cabeceiras de drenagem em anfiteatro e hídricas (cursos d'água e canais de escoamento).

No caso do município de Ituiutaba/MG, são poucos os mapeamentos geomorfológicos que detalham aspectos do relevo. Na tentativa de contribuir para a disseminação dessa técnica de mapeamento para outras áreas do município, para fins de planejamento ambiental, foi elaborada uma carta representando os compartimentos geomorfológicos da área de estudo, bem como as principais feições morfológicas e hídricas (Figura 11).

A elaboração do mapeamento geomorfológico que contemplou a paisagem geomorfológica da Serra do Corpo Seco e seu entorno, possibilitou a identificação de seis compartimentos distintos, sendo eles:

- topos estreitos dos relevos tabuliformes (cor marrom escuro);

- vertentes associadas aos solos medianamente profundos e rampas de colúvios (cor amarelo ouro);

- vertentes associadas aos solos muito rasos (cor laranja);

- vertentes associadas aos solos profundos e com rampas suaves e alongadas (cor amarelo claro);

- topos amplos suavemente convexizados das colinas (cor marrom claro); 
- vertentes associadas aos solos bastante profundos (cor amarelo limão).

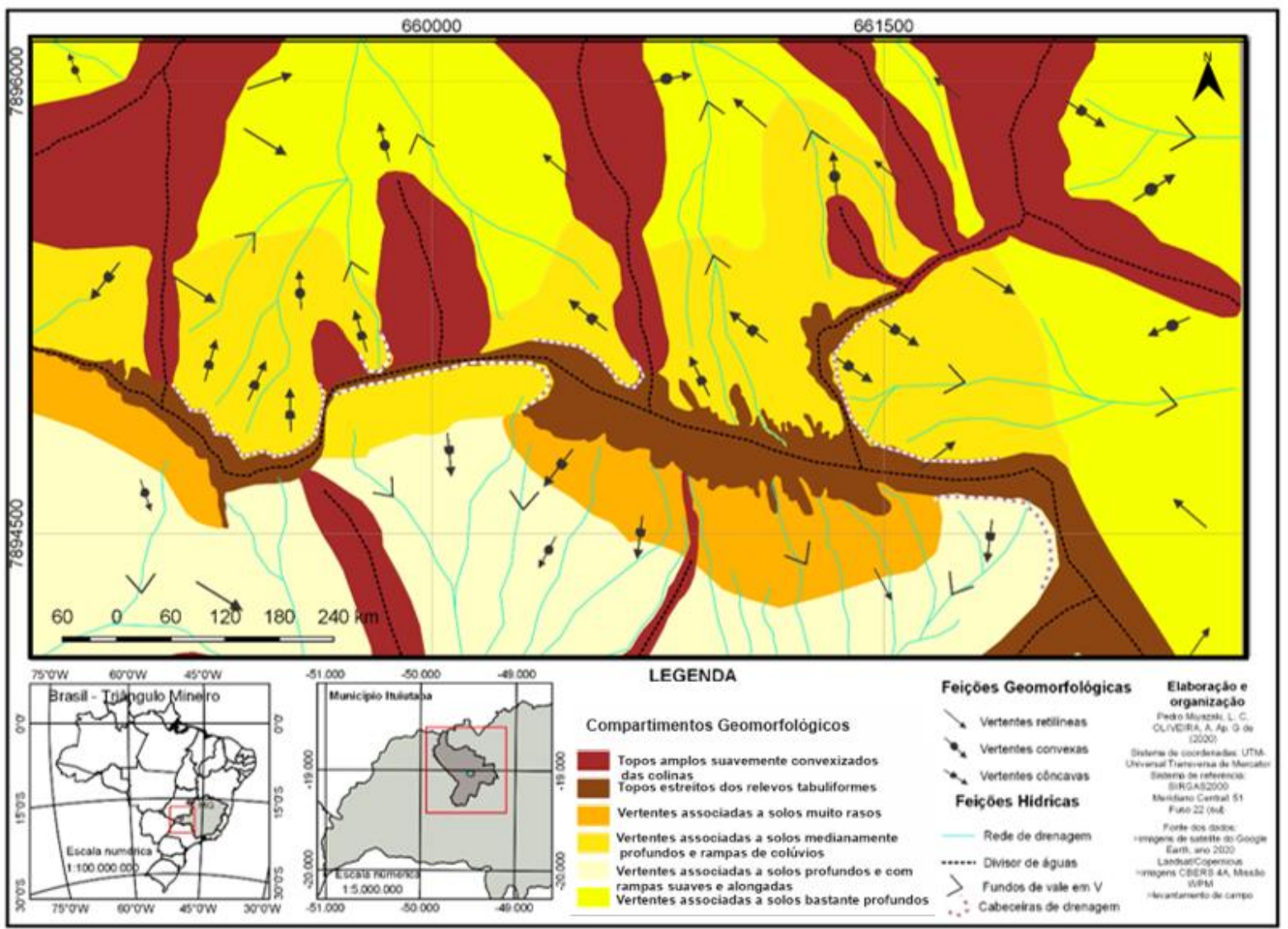

Figura 11: Mapeamento dos compartimentos geomorfológicos, feições hídricas e do relevo da Serra do Corpo Seco

O primeiro compartimento identificado envolveu a área dos topos estreitos dos relevos residuais ou tabuliformes (Figura 12). Nesse compartimento foram encontrados vários divisores de águas de bacias hidrográficas localizadas nas proximidades da área urbana e rural do município, por exemplo os divisores das bacias do São José, Pirapitinga, Carmo e São Vicente, cujas características marcantes são os topos planos, estreitos e alongados com várias ramificações que formam um espigão divisor de águas. Altitudes encontradas variam entre 660 a 690 metros e com declividades superiores aos $30 \%$.

Para Pedro Miyazaki (2018), esses tipos de relevos possuem formas características a mesas ou tabuleiros, tendo seu topo aplainado e vertentes íngremes, sendo sustentados pela presença de camadas sedimentares que possuem resistência litológica variada. 


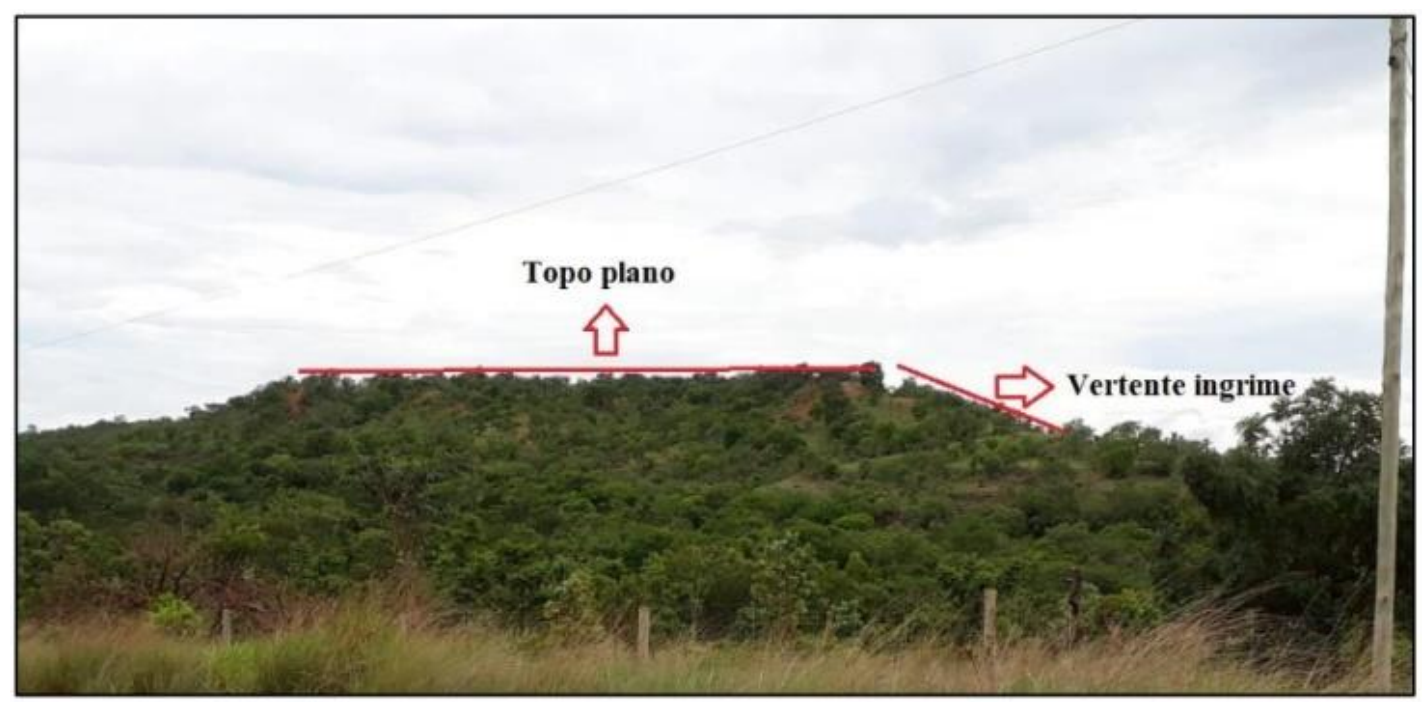

Figura 12: Relevo residual do tipo tabuliforme, com exemplo de topo estreito e alongado e vertentes íngremes.

Fonte: Oliveira (2019)

Os relevos residuais, como a Serra do Corpo Seco, possuem vertentes associadas a solos medianamente profundos e rampas de colúvios (Figura 13), compondo o segundo compartimento espacializado. Essas vertentes apresentam um comprimento de rampa mais suave e alongado, compostas por um material sedimentar bastante consolidado e solos que apresentam média profundidade. Essas características estão ligadas a ação dos agentes exógenos que atuaram constantemente intemperizando a rocha matriz além de denudar o relevo tabuliforme. Atualmente é possível observar que essas vertentes têm uma camada regolítica espessa e com a presença de vegetação rasteira e arbustiva. Foram identificadas altitudes que variam entre $640 \mathrm{a}$ 660 metros e declives de 8 a $20 \%$

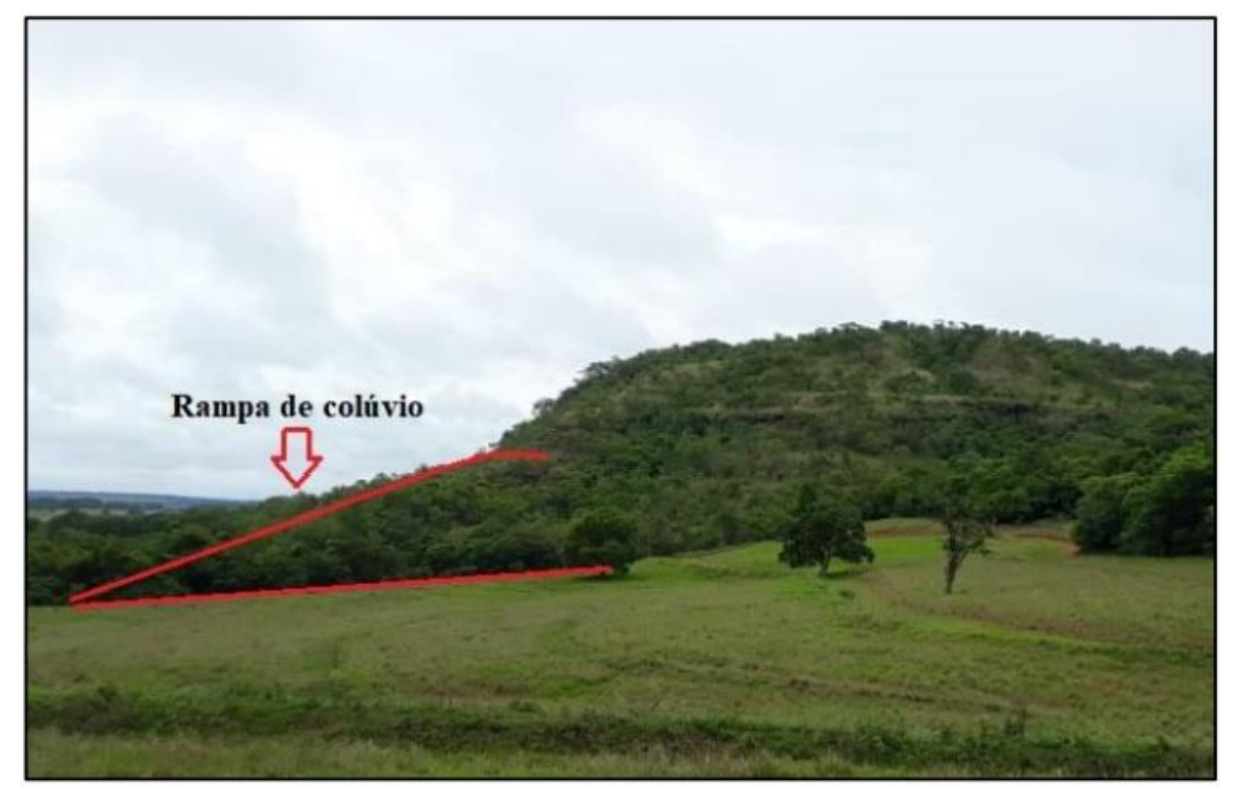

Figura 13: Relevo residual do tipo tabuliforme, com exemplo rampa de colúvio coberto por vegetação arbustiva e rasteira

Fonte: Oliveira (2019) 
As vertentes associadas a solos muito rasos (Figura 14) compreendem o terceiro compartimento evidenciado, podem ser identificadas quando apresentam a exposição da rocha matriz de origem sedimentar (vertentes litólicas).

No caso da Serra do Corpo Seco, é perceptível a exposição de planos inclinados, bastante verticais expondo os arenitos e a alternância de resistência das camadas, que ora se apresentam friáveis e com marcas da atuação da erosão, ora resistentes com a preservação da camada que corresponde a cornija. Esse aspecto é típico da Formação Marília, do Grupo Bauru. As altitudes variam entre 580 e 660 metros e a declividade corresponde ao intervalo de 30 a $45 \%$ e a cobertura vegetal é incipiente ou inexistente em alguns setores.

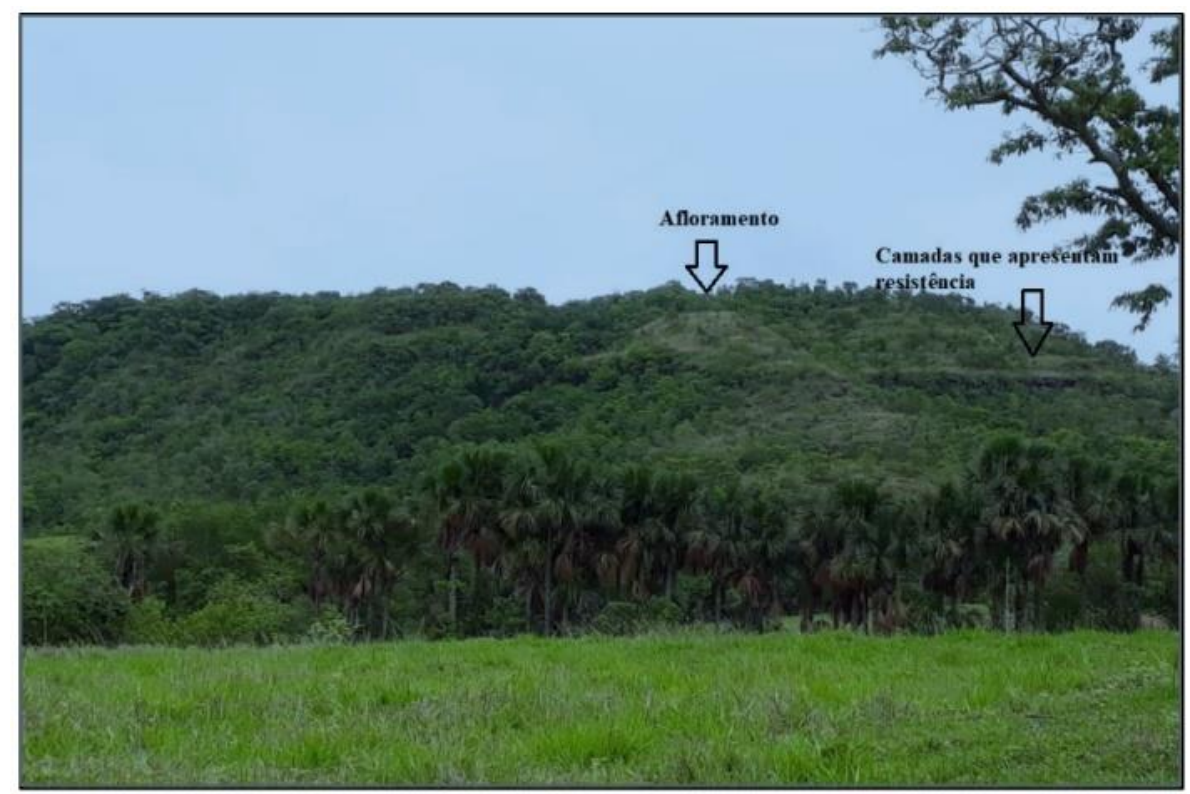

Figura 14: Relevo residual do tipo tabuliforme, com exemplo de vertentes associadas a solos muito rasos e exposição da cornija.

Fonte: Oliveira (2019)

Outro compartimento mapeado na Serra do Corpo Seco foram os topos amplos suavemente convexizados das colinas (Figura 15). Esse compõe o relevo de colina, que é marcada pelo rebaixamento denudacional das ações dos processos operantes (denudação e dissecação), fazendo surgir as colinas com topos amplos suavemente convexizadas. As altitudes variam entre 560 e 660 metros e a declividade está associada ao intervalo de classes de 8 a $30 \%$, com a presença de algumas áreas com vegetação de médio porte e áreas de cultivo e pastagem. 


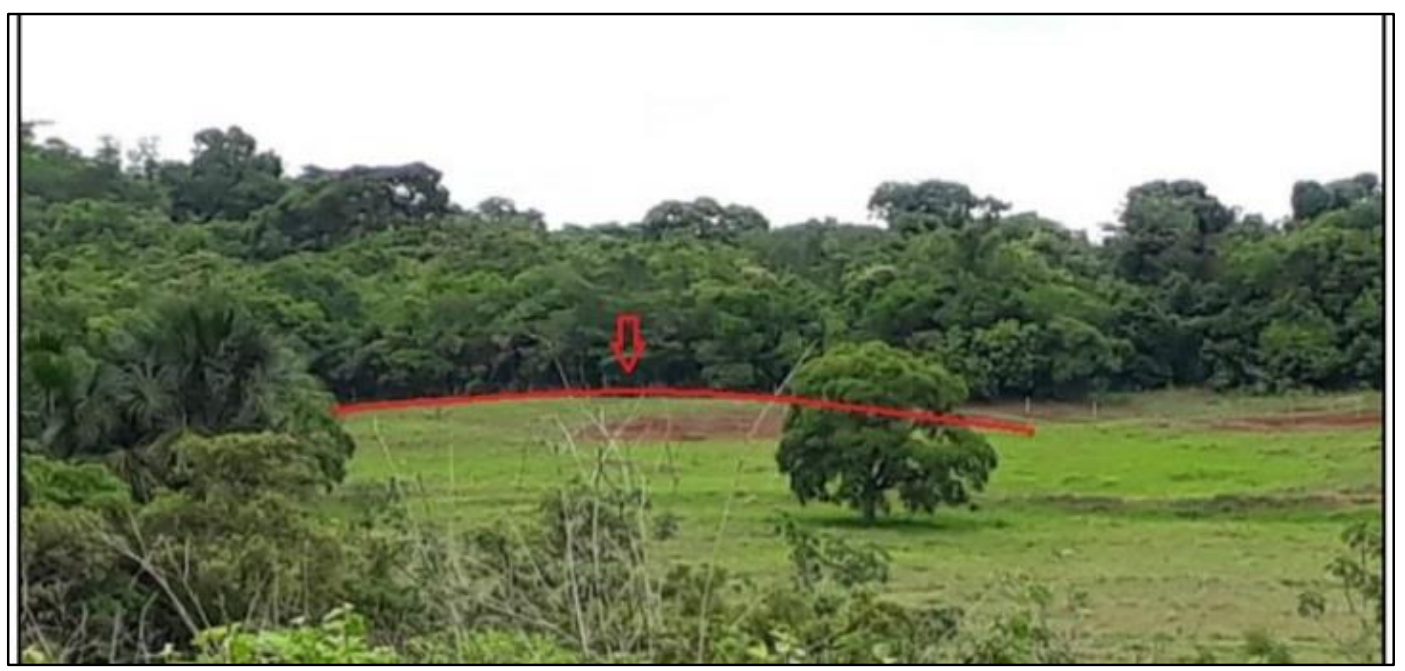

Figura 15: Relevo de colinas, com exemplo de topo amplo suavemente convexizado.

Fonte: Oliveira (2019)

As vertentes associadas a solos bastante profundos estão vinculadas ao relevo de colinas, com topos amplos suavemente convexizados (Figura 16), cujos planos inclinados são longos e as declividades são suaves, além de possuir um manto de intemperismo bastante espesso. As altitudes variam entre 560 e 650 metros e as declividades envolvem o intervalo de 3 a $8 \%$. Em relação à cobertura vegetal é possível encontrar manchas de vegetação médio e grande porte e áreas de cultivo e pastagem.

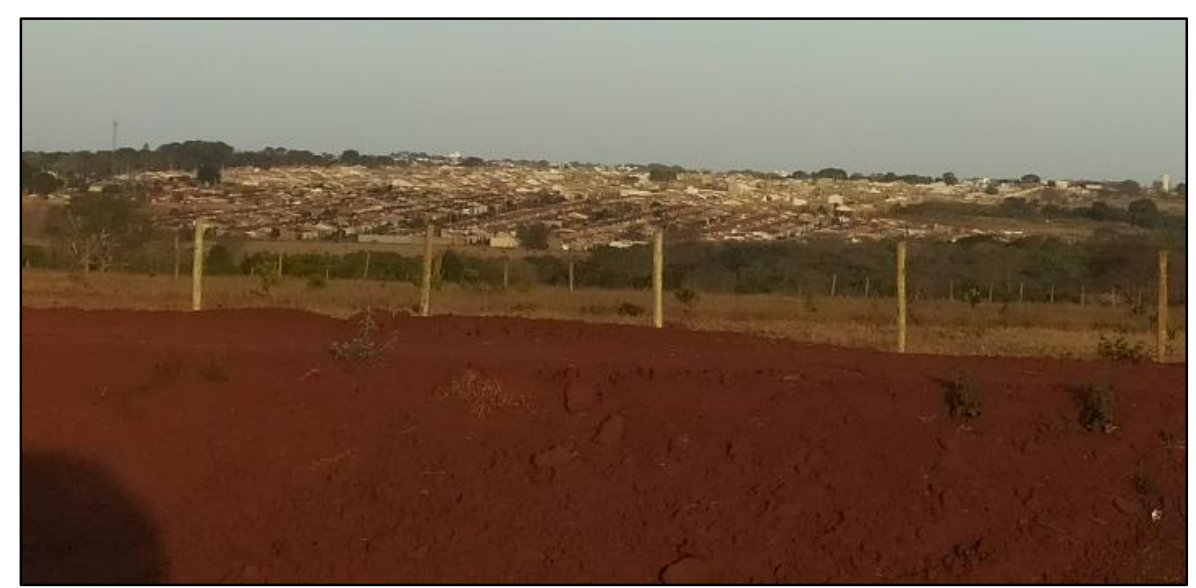

Figura 16: Relevo de colinas, com exemplo de vertentes com comprimento de rampa longo, pouco declivoso e um rególito espesso, apresentando como cobertura vegetal predominante a pastagem. Fonte: Oliveira (2019)

A vertentes associadas a solos profundos e com rampas suaves e alongadas (Figura 17) se encontram conectadas aos relevos residuais do tipo tabuliformes, onde estão ligadas aos sopés das vertentes litólicas, se estendendo até os fundos de vale dos afluentes do Ribeirão São Vicente. As altitudes variam entre 550 e 580 metros e as declividades são inferiores a 3\%. 


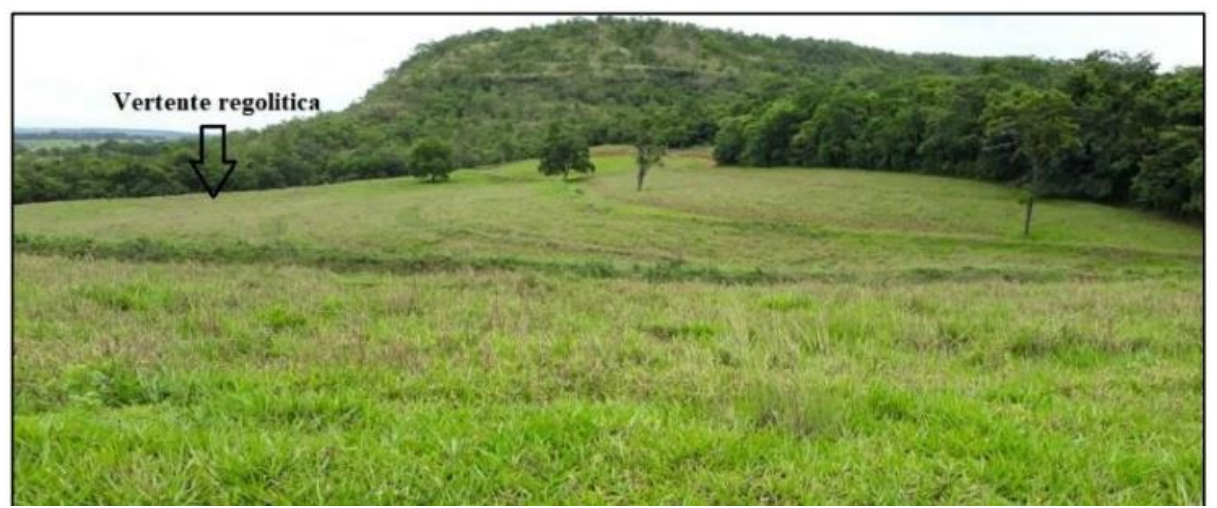

Figura 17: Relevo de colinas, exemplo de vertentes com comprimento de rampa alongado e extremamente suave.

Fonte: Oliveira (2019)

Para além dos compartimentos mapeados o método do anáglifo associado a fotointerpretação e as imagens de satélite e alta resolução espacial permitiram que as feições geomorfológicas fossem vistas com mais precisão devido à possibilidade de enxergar a área de estudo em alto relevo, em três dimensões. Deste modo, foram identificadas quatro feições geomorfológicas, sendo elas:

- vertentes côncavas;

- vertentes convexas;

- vertentes retilíneas;

- cabeceira de drenagem em anfiteatro.

$\mathrm{Na}$ carta, as feições foram representadas por símbolos, facilitando assim a identificação, além de possibilitar uma interpretação e visualização das formas do relevo representadas por meio da associação de simbologia e das imagens de registro. É de suma importância a identificação das vertentes, pois são formas onde ocorrem os processos morfogenéticos de esculturação do relevo, sendo consideradas como categoria de análise fundamental para o estudo geomorfológico.

A vertente côncava (Figura 18) no relevo residual fica próxima às cabeceiras de drenagem permitindo a maior infiltração da água, é a área que possui menos vegetação, pois sofre com mais intensidade os processos pedogenéticos. 


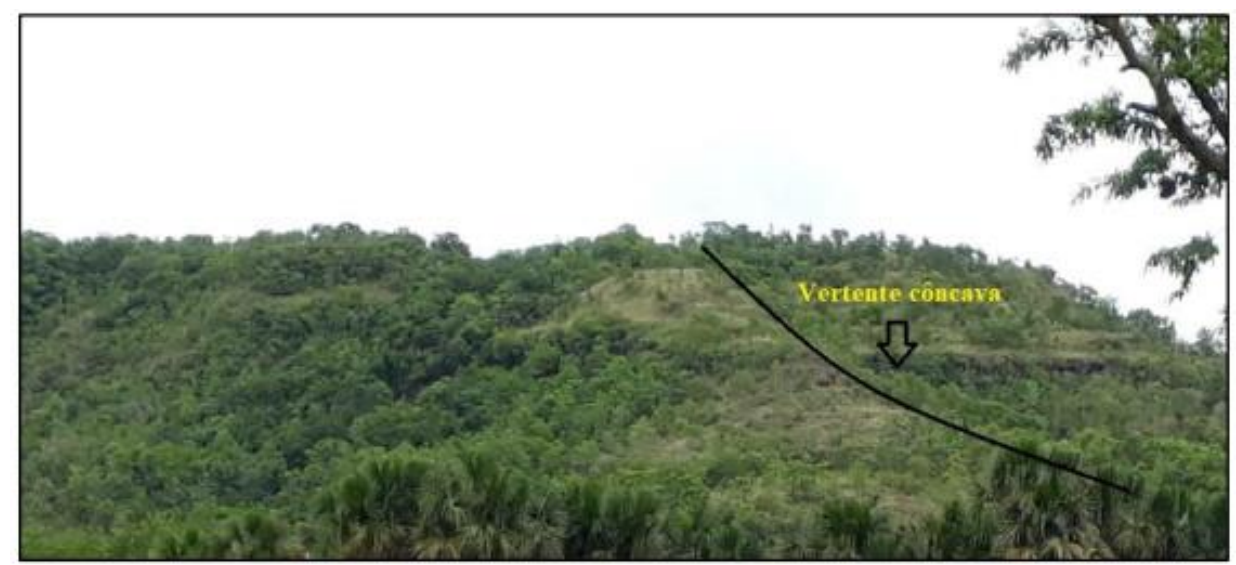

Figura 18: Relevo de colinas, exemplo de vertentes com comprimento de rampa alongado e extremamente suave

Fonte: Oliveira (2019)

Segundo Casseti (2005), a vertente convexa (Figura 19) ocorre quando os efeitos denudacionais não acompanham o entalhamento do talvegue, levando em consideração a base local e o soerguimento.

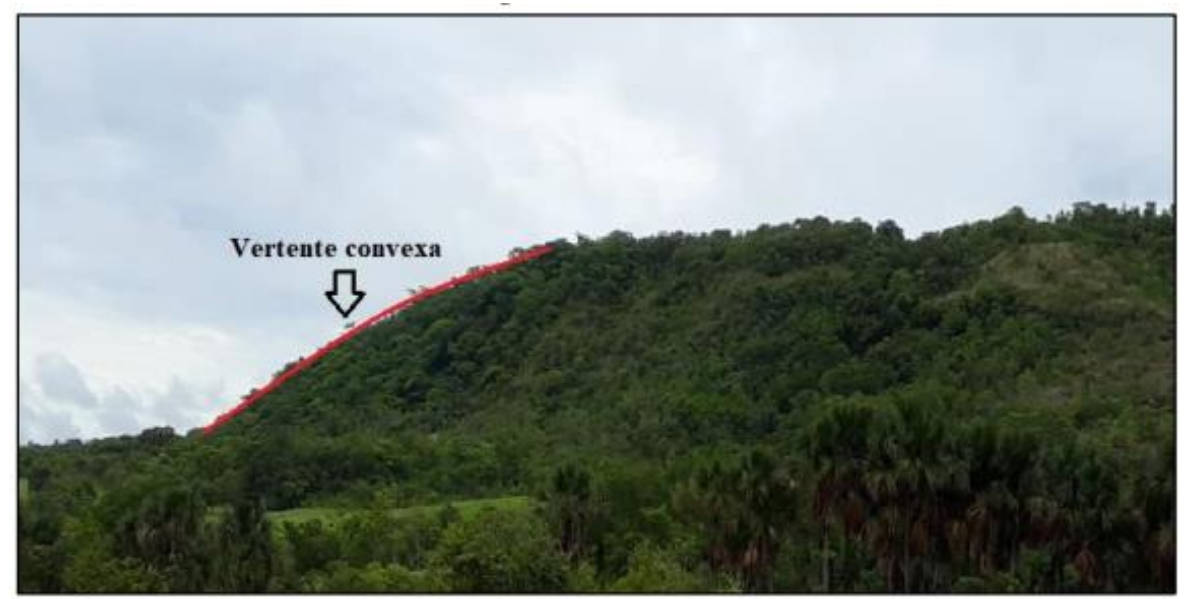

Figura 19: Relevo de colinas, exemplo de vertentes com comprimento de rampa alongado e extremamente suave.

Fonte: Oliveira (2019)

No relevo residual Serra do Corpo Seco, a vertente convexa se caracteriza por ser bem esculpida, com vegetação presente. Seu formato dificulta a infiltração da água, tornando assim o escoamento difuso e ocasionando o surgimento de pequenas erosões, como por exemplo, sulcos ou ravinas.

As vertentes retilíneas (Figura 20) podem ser definidas quando o soerguimento da crosta é moderado, os efeitos denudacionais seguem a mesma intensidade do entalhamento do talvegue ou uma manutenção do ângulo da declividade, desenvolvendo então a feição retilínea (Casseti, 2005). 


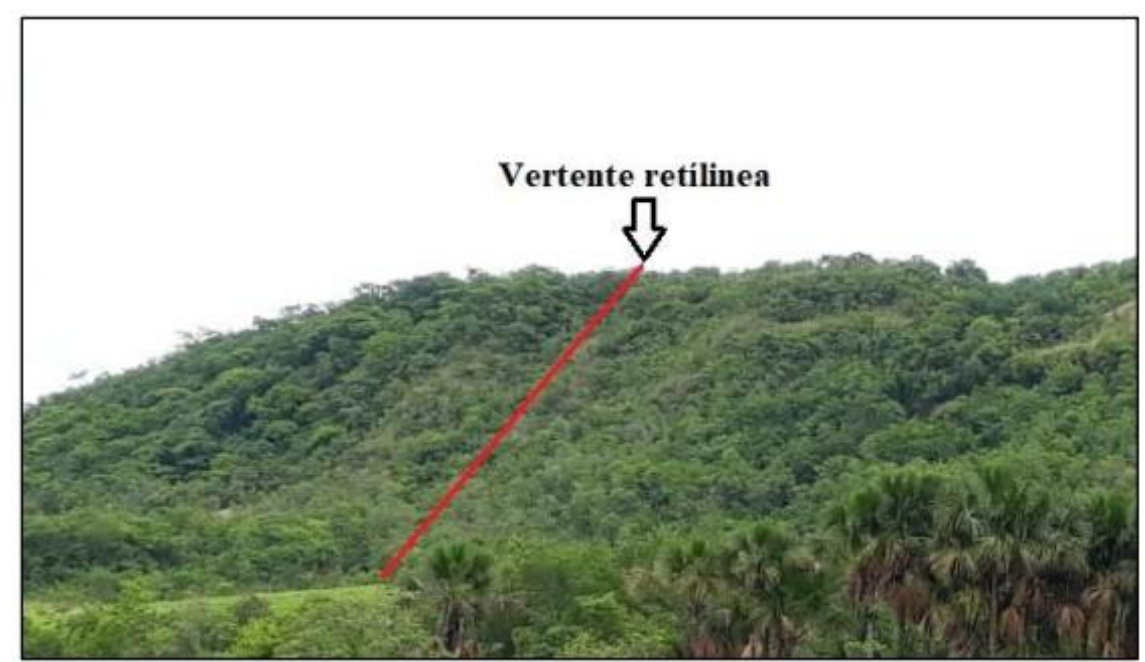

Figura 20: Relevo de colinas, exemplo de vertentes com comprimento de rampa alongado e extremamente suave.

Fonte: Oliveira (2019)

$\mathrm{Na}$ área de estudo, segundo o mapeamento geomorfológico, esse tipo de vertente é encontrado em áreas onde predomina o compartimento de vertentes regolíticas e próximas a canais de escoamento. Seu formato extenso e em rampa faz com que a água escoe de forma superficial, podendo causar erosões lineares (Pedro Miyazaki, 2017).

A última feição geomorfológica identificada no mapeamento foi a cabeceira de drenagem em anfiteatro (Figura 21). Segundo Guerra e Guerra (2006), essa feição pode ser definida como um "olho d'água" utilizado para identificar nascentes de canais fluviais.

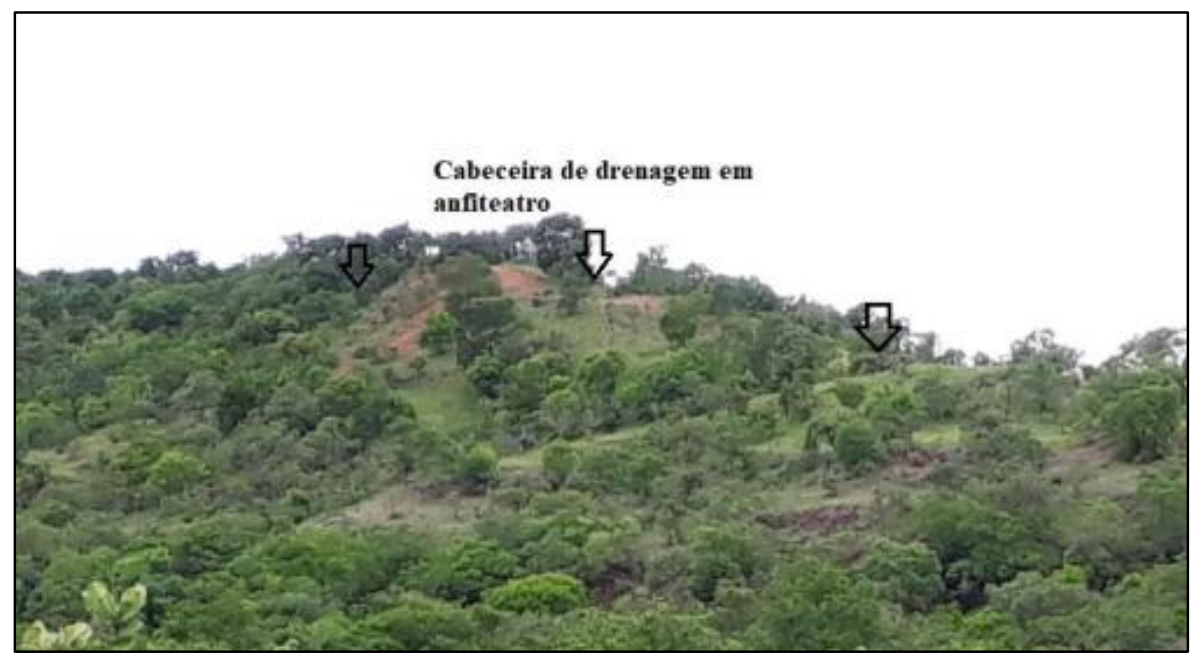

Figura 21: Relevo de colinas, exemplo de vertentes com comprimento de rampa alongado e extremamente suave

Fonte: Oliveira (2019) 
No mapeamento geomorfológico, foram representadas seis cabeceiras de drenagem em anfiteatro. Sua identificação é fácil de ocorrer devido a sua forma côncava e a densa vegetação (mata ciliar). Ambas as cabeceiras se encontram na borda da vertente regolítica associada a rampas de colúvio.

Além dos compartimentos e feições geomorfológicas, foi possível espacializar as feições hídricas que são compostas pelos canais de escoamento e os fundos de vale em V.

Durante o mapeamento, percebeu-se que os canais de escoamento se concentram em vertentes côncavas. Os canais variam de tamanho e de entalhamento, alguns sendo bem encaixados e conseguem manter um fluxo de água constante, podendo ser considerado um afluente.

$\mathrm{Na}$ área que o mapeamento foi realizado, o fundo de vale encontrado foi no formato em V, localizado nos canais de escoamento da cabeceira de drenagem em anfiteatro. Como visto, os fundos de vale em $V$ são característicos por possuírem os canais mais encaixados.

\section{Conclusões}

O estudo dos aspectos geomorfológicos da área de pesquisa, foi pautado em técnicas de mapeamento geomorfológico acessíveis e de fácil utilização (cujas bases cartográficas e os programas estão disponíveis gratuitamente), privilegiando a escala de análise do local (grandes escalas cartográficas), mapeamento de detalhe ou semidetalhado e vinculada às Geotecnologias. Com isso, foi possível espacializar os compartimentos geomorfológicos, os aspectos das feições hídricas e do relevo.

A utilização do método do anáglifo, associado a fotointerpretação e estereoscopia digital e imagens do Goggle Earth, além de programas como StereoPhoto Maker e QGIS permitiu gerar imagens tridimencionais facilitando a interpretação do mapeador, bem como a delimitação dos compartimentos geomorfológicos e feições hídricas e do relevo.

A identificação das feições deste relevo é de suma importância para a área de estudo, pois é o primeiro documento elaborado a partir da cartografia geomorfológica, podendo assim, ser utilizada como uma ferramenta para a realização do planejamento e gestão ambiental da área.

O documento cartográfico elaborado é uma importante ferramenta que poderá subsidiar o planejamento ambiental da área, uma vez que apresenta informações de caráter geomorfológico relevantes para os gestores do município, principalmente no que tange à proteção da Serra do Corpo Seco, que é reconhecida pela população como um patrimônio natural e cultural.

Espera-se que esse procedimento metodológico possa auxiliar outros pesquisadores na elaboração de mapeamentos geomorfológicos de detalhe ou semidetalhe, visando cada vez mais otimizar o tempo de elaboração. 


\section{Agradecimentos}

Agradecemos o apoio do Curso de Graduação e o Programa de Pós-graduação em Geografia pela infraestrutura concedida para realizar os trabalhos de campo e gabinete. Agradecemos também a equipe do Laboratório PEDOGEO e do Grupo de Pesquisa GEPDA.

\section{Financiamento}

Este trabalho não recebeu qualquer contribuição, financiamento ou bolsa de estudos.

\section{Bibliografia}

Balatka, B., Sladek, J. (1967). Problem of the conception of the detailed geomorphological map. In Demek, J. (ed) Progress made in geomorphological mapping (p. 179-192). Brno: IGU Commission on Applied Geomorphology.

Barcelos, J. H. (1984). Reconstrução paleogeográfica da sedimentação do Grupo Bauru baseada na sua redefinição estratigráfica parcial em território paulista e no estudo preliminar fora do estado de São Paulo. Tese Livre Docência, Instituto de Geociências e Ciências Exatas, Universidade Estadual Paulista, Rio Claro;

Casseti, V. (2005). Geomorfologia.

Cunha, C. M. I., Mendes, I. A., Sanchez, M. C. (2003). A cartografia do relevo: uma análise comparativa de técnicas para a gestão Ambiental. Revista Brasileira de Geomorfologia, 4(1), 1-9. Consultado em: http://www.lsie.unb.br/rbg/index.php/rbg.

Cunha, C. M. L. da, Queiroz, D. S. (2012). A cartografia geomorfológica de detalhe: uma proposta visando à multidisciplinaridade. Revista CLIMEP - Climatologia e Estudos da Paisagem, 7(1-2), 22-45. Consultado em: http://www.periodicos.rc.biblioteca.unesp.br/index.php/climatologia/article/view/5339.

Fernandes, L. A. (1998). Estratigrafia e evolução geológica da parte oriental da Bacia Bauru (Ks Brasil). Tese de Doutorado. Instituto de Geociências, Universidade de São Paulo, São Paulo.

Fushimi, M. (2009). Mapeamento Geomorfológico do Município de Presidente Prudente-SP. Monografia de Bacharelado. Universidade Estadual Paulista, Faculdade de Ciências e Tecnologia, campus de Presidente Prudente.

Girão, O., Corrêa, A. C. B. (2004). A contribuição da geomorfologia para o planejamento da ocupação de novas áreas. Revista de Geografia, 21(2), 36-58.

Google Earth (2020). Google Earth website. http://earth.google.com/,2009.

Griffiths, J. S., Abraham, J. K. (2008). Factors affecting the use of applied geomorphology maps to communicate with different end-user. Journal of maps, 4(1), 201-210. https://doi.org/10.4113/jom.2008.89

Guerra, A. T., Guerra, A. J. T. (2006). Novo Dicionário geológico-geomorfológico. 5aㅡ ed. Rio de Janeiro: Bertrand Brasil.

IBGE (1979). Ituiutaba. Folha topográfica de Ituiutaba. Rio de Janeiro: Centro de Serviços Gráficos do IBGE, 1973. Escala 1:100.000. 1 folha, color., Folha SE-22-Z-B-IV. Disponível 
em: http://biblioteca.ibge.gov.br/index.php/biblioteca-catalogo?view=detalhes\&id=6401. Acesso: 25 novembro 2014.

IBGE (2010). Cidades. Consultado em 12 de setembro de 2020 em: http://www.cidades.ibge.gov.br/xtras/perfil.php?lang=\&codmun=313420\&search=\|infogr\% E1ficos:-informa\%E7\%F5es-completas.

Lima, K. C., Cunha, C. M. L. da, Filho, A. P. (2013). Dificuldades e possibilidades da cartografia geomorfológica no semiárido brasileiro. Revista Brasileira de Cartografia, 65(6), 11. Consultado em: http://www.seer.ufu.br/index.php/revistabrasileiracartografia/article/view/43880/23144.

Malvezzi. C. M., Oliveira, A. A. G. de, Pedro Miyazaki, L. C., Lima, T. M., Silva, A. dos S., Santos, K. P. dos (2017). Identificação dos principais impactos ambientais no relevo residual morro São Vicente/Serra do Corpo Seco. IX Encontro GEOPONTAL.

Nunes, J. O. R., Freire, R., Peres, I. U. (2006). Mapa geomorfológico do perímetro urbano da cidade de Presidente Prudente. In VI Simpósio Nacional de Geomorfologia e Regional Conference on Geomorphology, Goiânia. Anais...CDROM.

Oliveira, A. A. G. (2020). A Utilização de anáglifos aplicado ao mapeamento geomorfológico: o caso do relevo residual "Serra do Corpo Seco". Trabalho de Conclusão de Curso (Graduação em Geografia) - Universidade Federal de Uberlândia, Uberlândia.

Pedro, L. C. (2011) Geomorfologia Urbana: impactos no ambiente urbano decorrente da forma de apropriação, ocupação do relevo. Geografia em Questão, 4(1), 153-172. Consultado em: http://e-revista.unioeste.br/index.php/geoemquestao/issue/view/354.

Pedro Miyazaki, L. C. (2014). Dinâmicas de apropriação e ocupação em diferentes formas de relevo: análise dos impactos e da vulnerabilidade nas cidades de Presidente Prudente/SP e Marília/SP. Tese de Doutorado, Universidade Estadual Paulista, Faculdade de Ciências e Tecnologia, campus de Presidente Prudente.

Pedro Miyazaki, L. C. (2016). Espacialização dos compartimentos geomorfológicos de parte da área urbana de Ituiutaba-MG. In XVIII Encontro Nacional de Geógrafos. São Luís. A construção do Brasil: geografia, ação política e democracia (p.1-13). São Luís: UFMA. Anais, 1.

Pedro Miyazaki, L. C. (2017). Elaboração da carta de compartimentação geomorfológica para estudo do relevo na área urbana de Ituiutaba (MG). Espaço em Revista, 19(2), 1-17. Consultado em: https://www.revistas.ufg.br/espaco/article/download/49966/25238.

Pedro Miyazaki, L. C., Bento, L. C. M. (2018). Possibilidades didáticas do geomorfossítio Salto da Prata - Ituiutaba/MG. ANAIS...XII SINAGEO.

Sherman, G. E., Sutton, T., Blazek, R., Holl, S., Dassau, O., Morely, B., Mitchell, T., Luthman, L. (2011). Quantum GIS User Guide - Version 1.7 "Wroclaw". Consultado em 20 de agosto de 2018 em: http://download.osgeo.org/qgis/doc/manual/qgis-1.7.0 user guide en.pdf.

Soares, A. Q., Fujimoto, N. S. V. M. (2009). Caracterização e compartimentação do relevo dabacia hidrográfica do rio do Silveira - São José dos Ausentes - RS. Anais eletrônicos do Simpósio Brasileiro de Geografia Física Aplicada. Viçosa. Consultado em 29 de junho de 2020 em: http://www.geo.ufv.br/simposio/.

Software StereoPhoto Maker. Disponível em: http://stereo.jpn.org/eng/stphmkr/. 
Souza, T. de A., Oliveira, R. C. (2012). Avaliação da potencialidade de imagens tridimensionais em meio digital para o mapeamento geomorfológico. Revista GEONORTE, Edição Especial, 2(4), 1348-1355. Consultado em: http://www.periodicos.ufam.edu.br/revistageonorte/article/view/2193/2064.

Suertegaray, D. M. A., Nunes, J. O. R. (2001). A natureza da Geografia Física na Geografia. Revista Terra Livre, 17, 11-24. Consultado em: https://www.agb.org.br/publicacoes/index.php/terralivre/article/view/337/319.

Artigo recebido em/ Received on: 15/10/2020

Artigo aceite para publicação em/ Accepted for publication on: 08/12/2020 
Pedro Miyazaki e Oliveira / Physis Terrae, Vol. 2, nำ 2, 2020, 43-65

Página intencionalmente deixada em branco 